\title{
PHASE EQUILIBRIA STUDY OF SYSTEMS COMPOSED OF MACAUBA PULP OIL (Acrocomia aculeata), FREE FATTY ACIDS, AND HYDROUS ETHANOL AT $25^{\circ} \mathrm{C}$
}

\author{
ESTUDO DO EQUILÍBRIO DE FASES DE SISTEMAS COMPOSTOS POR ÓLEO \\ DE POLPA DE MACAÚBA (Acrocomia aculeata), ÁCIDOS GRAXOS LIVRES E \\ ETANOL HIDRATADO A $25^{\circ} \mathrm{C}$
}

\author{
D. B. REZENDE ${ }^{1}$, M. H. C. ANDRADE ${ }^{2}$, V. M. D. PASA ${ }^{1}$ \\ ${ }^{1}$ Universidade Federal de Minas Gerais, Department of Chemistry, Brazil \\ ${ }^{2}$ Universidade Federal de Minas Gerais, Department of Chemical Engineering, Brazil \\ E-mail: bastos_rezende@hotmail.com.br
}

\author{
$\underline{\operatorname{article} i n f o}$ \\ Article history: \\ Received 2017-05-18 \\ Accepted 2017-08-31 \\ Available online 2017-11-20
}

KEYWORDS: Liquid-liquid equilibrium; free fatty acids; Acrocomia aculeata; solvent extraction.

PALAVRAS-CHAVE: Extração líquido-líquido; ácidos graxos livres; Acrocomia aculeata; extração

\begin{abstract}
The deacidification of vegetable oil by liquid-liquid extraction is based on the difference in solubility of the free fatty acids and triacylglycerols in the solvent. In the present study, the determination of the phase diagram of the liquid-liquid equilibrium for a pseudo-ternary mixture of solvent (ethanol and water), neutral oil (triglycerides) and free fatty acids was performed. It is important to highlight that the macauba pulp oil sample used in this work was not submitted to any kind of treatment such as degumming or neutralization. Therefore, the free fatty acids in the sample are resulted from natural degradation of the macauba oil. Despite of that, the results were similar to those found in other studies with purified macauba oil or other sources of triacylglycerols with the addition of oleic acid. The experimental data were correlated by NRTL model and the global deviation between experimental and calculated concentrations was $2.74 \%$.
\end{abstract}

RESUMO: A desacidificação de óleos vegetais através da extração líquido-líquido é baseada nas diferentes solubilidades dos ácidos graxos livres e dos triglicerídeos nos solventes. No presente trabalho, determinou-se o diagrama ternário de equilibrio de fases da mistura pseudo-ternária de óleo de polpa de macaúba, ácidos graxos livres e solvente (etanol hidratado). É importante ressaltar que as amostras de óleo de polpa de macaúba utilizadas neste trabalho não passaram por nenhum pré-tratamento como degomagem ou neutralização. Dessa forma, os ácidos graxos livres presentes na mistura são resultantes do processo de degradação natural do óleo. Apesar disso, os resultados encontrados foram similares aos resultados encontrados em estudos semelhantes com óleos de macaúba purificados e com adição de ácido oleico. Os parâmetros do modelo NRTL foram levantados a partir dos dados experimentais, obtendo-se em desvio de $2,74 \%$ entre os valores de concentração obtidos na prática e através do modelo. 


\section{INTRODUCTION}

With the worldwide growth in demand and prices of vegetable oils, the cultivation of oleaginous plants with high productivity of oil becomes necessary. Therefore, investments in research and development in extraction and refining of oils have been growing (COSTA, 2012).

Macauba is the Brazilian name commonly used to refer to the palm trees of the genus Acrocomia, Palmae family. The Acrocomia aculeata is the species of the greater dispersion in Brazil and it can produce more than 20 tons of fruit per hectare. In population between 100 and 216 palms per hectare, the yield of oil may range between $1500 \mathrm{~kg} \mathrm{ha}^{-1}$ to $5000 \mathrm{~kg} \mathrm{ha}^{-1}$ (COSTA et al., 2009). On average, mature and fresh fruits weigh about 50 grams and contain approximately $22 \% \mathrm{w} / \mathrm{w}$ of oil (LUCIANO et al., 2009).

In oils and fats, the presence of free fatty acids is related to the degradation of triglycerides. The degradation mechanisms depend on the type and concentration of fatty acids present in the oil (PARADISO et al., 2010). In the case of macauba (Acrocomia aculeata), its extractive harvest contributes to the production of oil with high content of free fatty acids, specially the oils extracted from the pulp of the fruit (REZENDE et al., 2016).

The deacidification step is performed usually through chemical or physical refining. In chemical refining, free fatty acids are neutralized by an alkali, usually sodium hydroxide, forming soup, which must be removed through centrifugation. Part of the neutral oil is carried by the soup, generating losses in the process. The neutral oil must be washed and dried to remove the soap and the humidity (ANTONIASSI, 1996). The chemical refining is not recommended to treat oil with high free fatty acids content due to the formation of soap and emulsification and, consequently, high losses of neutral oil and effluent generation (REIPERT et al., 2011). The neutral oil losses in the chemical refining of corn oil with free fatty acid content between $8 \%$ and $14 \%$ can reach $15 \%$ to $25 \%$ (RODRIGUES, 2011). The physical refining involves steam distillation. There is no limitation related to the content of free fatty acids. However, it demands a great amount of energy in operation (CVENGROS, 1995). The physical refining requires degummed oil with no gum, metals, pigments, waxes, dirt and moisture. The main disadvantage of physical refining is the production of oil with lower oxidative stability due to distillation temperatures (ANTONIASSI, 1996).

The deacidification of vegetable oil through liquid-liquid extraction is based on the difference in solubility of the free fatty acids and triglycerides in the solvent. The main advantages of liquid-liquid extraction compared to traditional methods of deacidification are the reduction of the neutral oil loss, the mild operating conditions (atmospheric pressure and room temperatures), the absence of reagents and catalysts, no effluent generation and recovery of the free fatty acids, by-product with good market value (RODRIGUES, 2011).

There are several works studying the extraction of free fatty acids of vegetable oils from different sources such as cotton, garlic, grape seed, sesame, babassu palm, canola, Brazil nuts, macadamia nuts, rice bran, sunflower, corn, olein and palm stearin, palm, jatropha, soy, and jojoba using ethanol and other solvents like methanol, n-propanol, isopropanol, butanol and its mixtures with water as extraction solvent (BHOSLE et al., 2011). However, these studies usually use neutral oil with the addition of specific free fatty acid 
such as oleic acid and linoleic acid. Moreover, oil samples used have been pre-treated via degumming and neutralization steps. In these studies, hydrous ethanol presented great results to extract free fatty acids from oil with low initial acidity (up to $5 \% \mathrm{w} / \mathrm{w}$ ) with good selectivity, always considering pre-treated oil and the addition of free fatty acid, instead of the use of naturally degraded oil (CHIYODA et al., 2010; CUEVAS et al., 2010; CUEVAS et al., 2009; GONÇALVES et al., 2016; GONÇALVES et al., 2007; OLIVEIRA et al., 2012).

This work aimed the extraction of free fatty acids of macauba pulp oil using hydrous ethanol, producing two products: raffinate phase, rich in neutral oil; and extract phase, rich in free fatty acids. The liquid-liquid equilibrium data were obtained from crude samples of macauba pulp oil without any pre-treatment step. Free fatty acids present in samples are the result of natural degradation of the macauba oil. The extractions were performed using hydrous ethanol (95\%) as solvent.

\section{MATERIALS AND METHODS}

For phase equilibrium data acquirement, the experiments were conducted with seven samples of macauba pulp oil with acidity from $3.30 \%$ to $31.9 \%$ by weight of oleic acid. The free fatty acids were not added in samples. The free fatty acids in the sample are resulted from natural degradation of the macauba oil. The oil was extracted from fruits collected on the campus of the Federal University of Minas Gerais, Brazil. All tests were performed using ethanol with purity of $95 \%$ (hydrous ethanol) with ethanol-oil weight ratio of $1: 1$. This weight ratio was chosen based in previous works. Different weight ratio could be used if there was phase separation. After the thermodynamic modeling, any other ratio can be simulated. For each experiment, macauba oil was vigorously mixed with the solvent for 30 minutes in beaker with magnetic stirring. The phase separation took place in separating funnel for 1 hour, at the same temperature of the test, $25 \pm 2^{\circ} \mathrm{C}$.

After phase separation, the composition of each phase (raffinate and extract) was determined. The free fatty acid content was determined by acid-base titration (AOCS, 2017) and the solvent content was determined by evaporative loss. The samples were placed in Petri dishes in the amount of 1 to $2 \mathrm{~g}$ and weighed on analytical balance. After that, the samples were maintained in oven with air circulation at $105^{\circ} \mathrm{C}$ for 60 minutes. After evaporation, the solvent amount is estimated by mass loss of the samples. The triglycerides percentage is determined indirectly by difference. The compositions of each phase for every mixture tested were used to plot the phase diagram. The bimodal curve (phase equilibrium curve) was built by polynomial regression.

The experimental equilibrium data determined in this work were used to adjust the parameters of the NRTL model, calculated by the software ASPEN PLUS 8.2 regression tool. Because of the large difference in molecular weight of the components, mass fraction was used as unity of concentration (GONÇALVES; MEIRELLES, 2004). The activity coefficient assumes the following form: 


$$
\ln \left(\gamma_{i}\right)=\frac{\sum_{j=1}^{K} \frac{\tau_{j i} G_{i i} W_{j}}{\bar{M}_{j}}}{\sum_{j=1}^{K} \frac{G_{j i} W_{j}}{\bar{M}_{j}}}+\sum_{j=1}^{K}\left[\frac{W_{j} G_{j i}}{\bar{M}_{j} \sum_{l=1}^{n} \frac{G_{l j} W_{l}}{\bar{M}_{l}}}\left(\tau_{i j}-\frac{\sum_{l=1}^{K} \frac{\tau_{l j} G_{l j} W_{l}}{\bar{M}_{l}}}{\sum_{l=1}^{K} \frac{G_{l j} W_{l}}{\bar{M}_{l}}}\right)\right]
$$

Where:

$$
\begin{gathered}
G_{i j}=\exp \left(-\alpha_{i j} \tau_{i j}\right) \\
\tau_{i j}=A_{i j}+B_{i j} / T \\
\alpha_{i j}=\alpha_{j i}
\end{gathered}
$$

In the equations $1, A_{i j}, B_{i j}$ and $\alpha_{i j}$ are the interaction parateres of the NRTL model, $W$ is the mass fraction, $M$ is the molecular weight of the components or pseudo components, $K$ is the number of components or pseudo components, and $T$ is the equilibrium temperature $(\mathrm{K})$. The deviations between experimental and calculated compositions are calculated according to the equation 2 :

$$
\Delta w=100 \sqrt{\frac{\sum_{n}^{N} \sum_{i}^{K}\left[\left(W_{i, n}^{I, e x}-W_{i, n}^{I, c a l c}\right)^{2}+\left(W_{i, n}^{I, e x}-W_{i, n}^{I, c a l c}\right)^{2}\right]}{2 N K}}
$$

Where $N$ is the number of tie lines (GONÇALVES; MEIRELLES, 2004).

To determine the fatty acid composition of the macauba pulp oil, gas chromatography detection was performed according to the following procedure. The analyses were conducted using a gas chromatographer with a flame ionization detector (GC-FID). For injection of the samples, hydrolysis was performed, followed by methylation of the oils. For this purpose, approximately $10 \mathrm{mg}$ of oil were dissolved in $100 \mu \mathrm{L}$ of $95 \%$ ethanol with $5 \%$ of potassium hydroxide solution $\left(1 \mathrm{~mol} \mathrm{~L}^{-1}\right)$ in a vial. The samples were stirred for $10 \mathrm{~s}$. Next, they were heated for $20 \mathrm{~min}$ at $70{ }^{\circ} \mathrm{C}$ in a thermostatic bath. After cooling, $400 \mu \mathrm{L}$ of $20 \%$ hydrochloric acid and $600 \mu \mathrm{L}$ of ethyl acetate were added. After resting for $5 \mathrm{~min}, 300 \mu \mathrm{L}$ aliquot of the organic phase were removed, placed in vials and dried by evaporation, thus obtaining the free fatty acids. The free fatty acids were methylated with $100 \mu \mathrm{L}$ of $\mathrm{BF}_{3}$ with $14 \%$ methanol and heated for $10 \mathrm{~min}$ in water bath at $70{ }^{\circ} \mathrm{C}$. Next, they were diluted with $500 \mu \mathrm{L}$ of methanol and analyzed in the GC-2010 Shimadzu GC-FID. A $60 \mathrm{~m} \times 0.25 \mathrm{~mm}$ SP2340 column with film thickness of $0.20 \mu \mathrm{m}$ was used. The selected temperature gradient was maintaining 140 ${ }^{\circ} \mathrm{C}$ for $5 \mathrm{~min}$, heating at $4{ }^{\circ} \mathrm{C} \mathrm{min}^{-1}$ to $240{ }^{\circ} \mathrm{C}$, and remaining at this temperature for $9 \mathrm{~min}$. The temperatures of the injector and detector were $250{ }^{\circ} \mathrm{C}$ and $260^{\circ} \mathrm{C}$, respectively. Helium was used as the carrier gas, with a linear velocity of $28 \mathrm{~cm} \mathrm{~s}^{-1}$. The volume of injection was 1 $\mu \mathrm{L}$, and the split was $1 / 50$. The identification of the peaks was performed by comparison with the SUPELCO37 methylated fatty acid standards. 


\section{RESULTS AND DISCUSSION}

The system was considered pseudo ternary, consisting of triglycerides (neutral oil), free fatty acids and solvent (hydrous ethanol). The phase diagram, Figure 1, was built from the experimental equilibrium data obtained from the extractions. The results obtained in this work were plotted along with results available in the literature for extraction of oleic acid added into degummed and neutralized macauba pulp oil with hydrous ethanol (REZENDE, J. R., 2009) and extraction of free fatty acids present in degummed rice bran oil (OLIVEIRA et al., 2012). In the first study, the samples were stirred for 15 minutes using ethanol with $5.80 \%$ of water as extracting solvent and resting for 4 hours for phase separation. In the second study, the samples were vigorously stirred for 15 minutes using ethanol with $6.34 \%$ of water as extracting solvent, centrifuged for $10 \mathrm{~min}$ at $4500 \mathrm{~g}$, and allowed to rest for 6 hours at $35^{\circ} \mathrm{C}$. It can be seen in Figure 1 that both authors used samples with acidity up to $9.5 \%$, which makes it difficult to forecast the behavior for higher values of free fatty acids.

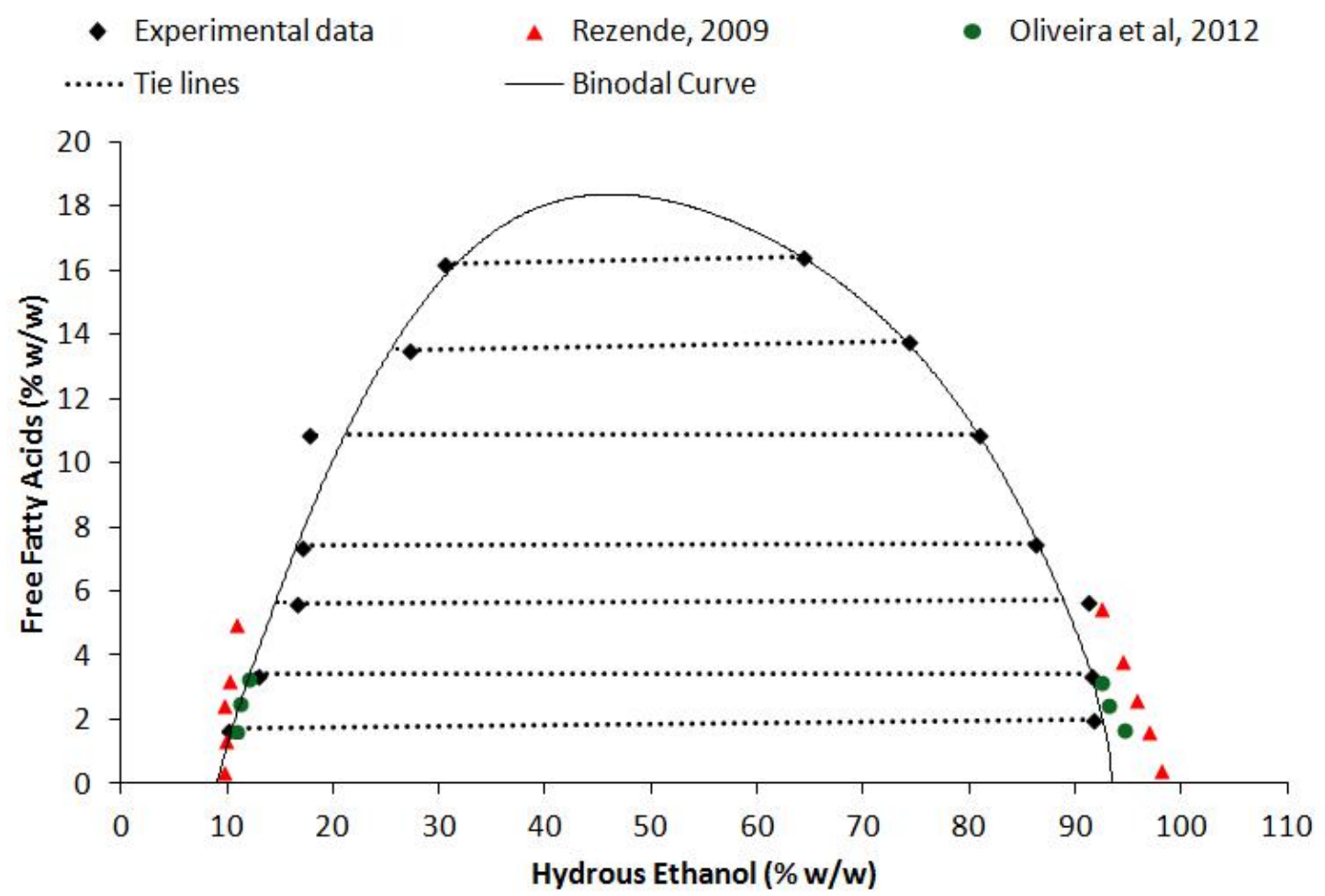

Figure 1 - Phase diagrams of the mixture triacylglycerols + free fatty acids + hydrous ethanol for experimental data and the results available in the literature (OLIVEIRA et al., 2012; REZENDE, 2009).

It is observed that the maximum miscibility limit is close to $20 \%$ of free fatty acids in the global composition, under the testing conditions. Concentration above this, it would become a single-phase system, making the extraction impossible. As can be seen, slopes of tie-lines are almost zero, which means that the partition coefficient of the free fatty acids between extract and raffinate are close to unit. 
The points close to the left corner of diagram correspond to the triglycerides rich phase, or raffinate. In this corner, the three results present the same behavior. However, the other corner, related to the solvent rich phase, the extract, it was observed a higher neutral oil loss in the present work, which can be associated with the presence of surfactants such as diglycerides and soluble impurities present in the oil, given the fact that no pre-treatment step, such as degumming, was performed in this work. Despite the best results achieved by using pre-treated oil, the difference is not significant enough to justify investment in pre-treatment steps.

For thermodynamic modeling of the experimental data, NRTL method (Non-random two-liquid) was adopted, which has shown good correlation with the experimental data in previous studies (GONÇALVES; MEIRELLES, 2004; OLIVEIRA et al., 2012; REIPERT; RODRIGUES; MEIRELLES, 2011; REZENDE, 2009). Table 1 shows the NRTL binary parameters for the experimental data. These values were calculated with the regression tool available in the software ASPEN PLUS 8.2, according to equation 1.

Table 1 - NRTL parameters for the system neutral oil (1) + free fatty acid (2) + hydrous ethanol (3) at $25^{\circ} \mathrm{C}$.

\begin{tabular}{c|c|c|c|c}
\hline Pair $\boldsymbol{i j}$ & $\boldsymbol{A} \boldsymbol{i j}$ & $\boldsymbol{A j i}$ & $\boldsymbol{B} \boldsymbol{j} \boldsymbol{j}(\boldsymbol{K})$ & $\boldsymbol{B j i}(\boldsymbol{K})$ \\
\hline 12 & -1.5626 & -1.4354 & -459.6600 & -434.4464 \\
13 & 12.3999 & 2.9591 & 3696.0835 & 905.6068 \\
23 & -1.4166 & -3.7982 & -387.9721 & -1138.1683 \\
\hline
\end{tabular}

The parameters $A_{i j}$ and $B_{i j}$ are binary interaction asymmetric parameters defined by regression of the experimental data used in the NRTL model for determining the activity. The symmetric $\alpha_{i j}$ parameter, defined in the ASPEN PLUS 8.2 as $c_{i j}$, was set at 0.3 , value commonly used for mixtures of nonpolar compounds and small deviations from ideality. The experimental data and data obtained from de NRTL model can be compared in Figure 2.

The global deviation between the experimental data and the calculated compositions, $\Delta w$, was $2.74 \%$. The deviation is considered high when compared to values found in the literature, such as $0.89 \%$ to extraction of oleic acid from refined corn oil, $0.33 \%$ for experiments with degummed and neutralized macauba oil and oleic acid and $0.35 \%$ for crude rice bran oil (OLIVEIRA et al., 2012; REZENDE, 2009). This difference may be associated with the non-ideal conditions used in the present study, which used macauba crude oil (with no pretreatment step as degumming, refining or neutralization) and fatty acids naturally found in macauba oil, the large acidity range evaluated and the short time of phase separation adopted. 


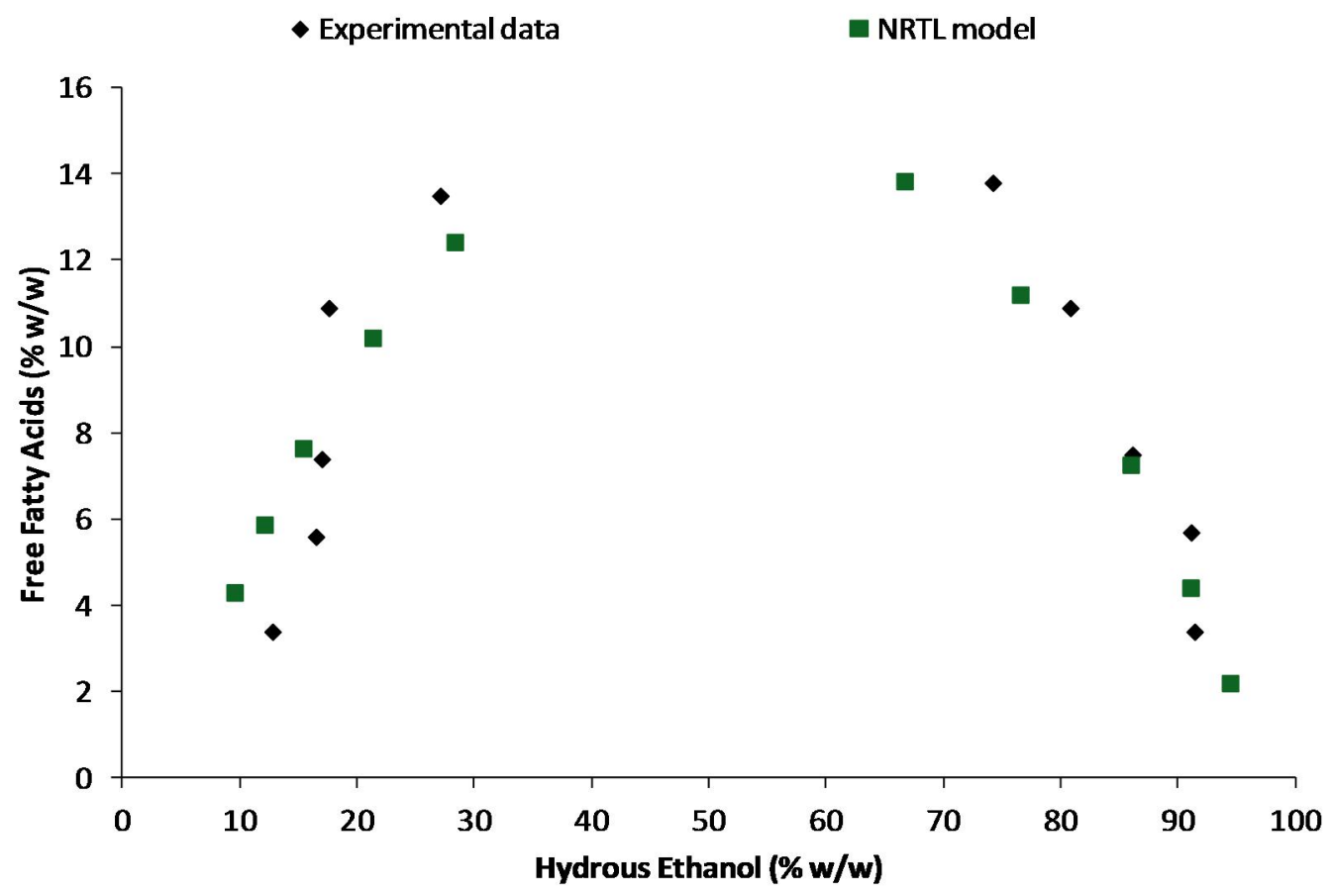

Figure 2 - Comparison between experimental data and NRTL model for hydrous ethanol.

After the extraction, the composition of the extract and the raffinate were determined by gas chromatography in order to verify if occurs selective extraction of some specific fatty acids. The compositions of both extract and raffinate are similar to the composition of the original oil. Hence, no selective extraction occurs at the process. To illustrate this conclusion, the compositions of the raffinate and extract obtained from the extraction of a sample with acidity of $12.9 \%$ are presented at Table 2 .

Table 2 - Fatty acid composition of macauba oil with acidity of $12.9 \%$, extract and raffinate from liquid-liquid extraction.

\begin{tabular}{l|c|c|c|c}
\hline \multirow{2}{*}{ Common name } & \multirow{2}{*}{ Notation } & \multicolumn{3}{|c}{ Oil composition (\% w/w) } \\
\cline { 3 - 5 } & & Original oil & Extract & Raffinate \\
\hline Tetradecanoic acid & $\mathrm{C} 14: 0$ & 0.04 & 0.06 & 0.04 \\
Palmitic acid & $\mathrm{C} 16: 0$ & 16.17 & 19.39 & 17.16 \\
Palmitoleic acid & $\mathrm{C} 16: 1$ & 1.91 & 2.53 & 2.22 \\
Stearic acid & $\mathrm{C} 18: 0$ & 2.79 & 2.72 & 2.89 \\
Oleic acid & $\mathrm{C} 18: 1$ & 66.52 & 61.47 & 65.61 \\
Linoleic acid & $\mathrm{C} 18: 2$ & 10.59 & 11.03 & 10.58 \\
Arachidic acid & $\mathrm{C} 20: 0$ & 0.13 & 0.15 & 0.16 \\
Linolenic acid & $\mathrm{C} 18: 3$ & 0.85 & 0.84 & 0.78 \\
\hline Others & 0.99 & 1.81 & 0.55 \\
\hline
\end{tabular}




\section{CONCLUSION}

The tests to determine the phase diagram of the liquid-liquid equilibrium for a pseudoternary mixture of solvent (hydrous ethanol), neutral oil (triglycerides) and free fatty acids were conducted differently to those found in the literature. The sample of macauba pulp oil used in this work did not undergo through any kind of pre-treatment, such as degumming and neutralization. The Free fatty acids content was the result of degradation of the macauba, unlike most of the studies available in the existing literature, in which a free fatty acid, such as oleic acid or linoleic acid, is added to the neutral oil to increase the acidity. Furthermore, the mixtures between the acid oil and the solvent were left to rest for only one hour to phase separation, while in some reference studies it was left up to 12 hours (GONÇALVES; MEIRELLES, 2004). Even with these conditions, the results were similar to those found in literature with macauba oil or other sources of triglycerides.

The experimental data were used to obtain the binary parameters of NRTL thermodynamic model for the liquid-liquid equilibrium. The global deviation between the experimental data and the calculated compositions was $2.74 \%$. The deviation is higher than those found in the literature using samples of degummed and neutralized oils with the addition of oleic or linoleic acid. However, due to the non-ideal conditions, the deviation found in the present work can be considered satisfactory.

\section{REFERENCES}

ANTONIASSI, R. Desacidificação de óleo de milho com etanol em coluna de discos rotativos (RDC). (Doctoral Dissertation) 1996. 188 p. UNICAMP, 1996.

AOCS. Official Method Cd 3d-63: Acid Value of Fats and Oils, 2017

BHOSLE, B. M.; SUBRAMANIAN, R. New approaches in deacidification of edible oils - A review. Journal of Food Engineering, v. 69, n. 4, p. 481-494, 2005.

CHIYODA, C. et al. Liquid-liquid equilibria for systems composed of refined soybean oil, free fatty acids, ethanol, and water at different temperatures. Fluid Phase Equilibria, v. 299, n. 1, p. 141-147, 2010.

COSTA, M. A.; SILVA, P. S. C.; VALLE, P. W. P. A. Bioenergia: Cadeia Produtiva e Coprodutos em Minas Gerais. Instituto de Estudos Pró-Cidadania. Belo Horizonte, MG: Instituto de Estudos Pró-Cidadania: SECTES, 2009.

COSTA, P. A. Integração dos processos de extração líquido-líquido e pervaporação para desacidificação do óleo de Macaúba (Acrocomia aculeata). (Master Thesis) 2012. 75 p. Universidade Federal do Rio de Janeiro - UFRJ, 2012.

CUEVAS, M. S. et al. Vegetable Oils Deacidification by Solvent Extraction: Liquid-Liquid Equilibrium Data for Systems Containing Sunflower Seed Oil at 298.2 K. Journal of Chemical \& Engineering Data, v. 55, n. 9, p. 3859-3862, 2010.

CUEVAS, M. S.; RODRIGUES, C. E. C.; MEIRELLES, A. J. A. Effect of solvent hydration and temperature in the deacidification process of sunflower oil using ethanol. Journal of Food Engineering, v. 95, n. 2, p. 291-297, 2009.

CVENGROS, J. Physical refining of edible oils. Journal of the American Oil Chemists' Society, v. 72, n. 10, p. 1193-1196, 1995.

GONÇALVES, C. B. et al. Deacidification of palm oil by solvent extraction. Separation and Purification Technology, v. 160, p. 106-111, 2016. 
GONÇALVES, C. B.; MEIRELLES, A. J. A. Liquid-liquid equilibrium data for the system palm oil + fatty acids + ethanol + water at 318.2 K. Fluid Phase Equilibria, v. 221, n. 1-2, p. 139-150, 2004.

GONÇALVES, C. B.; PESSÔA FILHO, P. A.; MEIRELlES, A. J. A. Partition of nutraceutical compounds in deacidification of palm oil by solvent extraction. Journal of Food Engineering, v. 81, n. 1, p. 21-26, 2007.

LUCIANO, M. A. et al. Caracterização físico-química do óleo da polpa da macaúba. in: 6th Brazilian Congress of Oleaginous, Oils, and Biodiesel. Annals of Congress... 2009, Montes Clasros, MG, Brazil: 2009.

OLIVEIRA, C. M.; GARAVAZO, B. R.; RODRIGUES, C. E. C. Liquid-liquid equilibria for systems composed of rice bran oil and alcohol-rich solvents: Application to extraction and deacidification of oil. Journal of Food Engineering, v. 110, n. 3, p. 418-427, 2012.

PARADISO, V. M. et al. Effects of free fatty acids on the oxidative processes in purified olive oil. Food Research International, v. 43, n. 5, p. 1389-1394, 2010.

REIPERT, É. C. D.; RODRIGUES, C. E. C.; MEIRELLES, A. J. A. Phase equilibria study of systems composed of refined babassu oil, lauric acid, ethanol, and water at $303.2 \mathrm{~K}$. The Journal of Chemical Thermodynamics, v. 43, n. 11, p. 1784-1790, 2011.

REZENDE, D. B.; ANDRADE, M. H. C.; PASA, V. M. D. Processo alternativo de desacidificação do óleo da polpa da macaúba (acrocomia aculeata) visando acoplamento em usinas de produção de biodiesel. The Journal of Engineering and Exact Sciences, v. 2, n. 3, p. 61-80, 2016.

REZENDE, J. R. Desacidificação de Óleo de Macaúba por Extração Líquido-Líquido, para Produção de Biodiesel. (Master thesis) 2009. 47 p. Universidade Estadual do Sudoeste da Bahia, 2009.

RODRIGUES, C. E. C. Utilização de solvente biorenovável nos processos de extração e desacidificação de óleos vegetais. (Habilitation Theses) 2011. 171 p. Universidade de São Paulo - USP, 2011. 